DOI: https://doi.org/10.24127/ajpm.v9i2.2703

\title{
KEMAMPUAN BERPIKIR KRITIS MATEMATIS BERDASARKAN DISPOSISI MATEMATIS
}

\author{
Asih Miatun', Hikmatul Khusna ${ }^{2}$ \\ ${ }^{1,2}$ Pendidikan Matematika, Univeristas Muhammadiyah Prof. Dr. HAMKA, Jakarta, \\ Indonesia \\ E-mail: $\quad$ asihmiatun@uhamka.ac.id ${ }^{\text {l) }}$ \\ hikmatulhusna@uhamka.ac.id $^{2)}$
}

Received 27 February 2020; Received in revised form 21 June 2020; Accepted 28 June 2020

\begin{abstract}
Abstrak
Penelitian ini bertujuan untuk mengkaji dan menganalisis secara mendalam kemampuan berpikir kritis matematis berdasarkan kemampuan disposisi matematis mahasiswa calon guru khususnya pada mata kuliah geometri. Penelitan ini dirasa penting karena tuntutan keterampilan matematika abad 21 yaitu, kreativitas, berpikir kritis, komunikasi, dan kolaborasi. Penelitian ini adalah penelitian deskriptif kualitatif dimana data utama pada penelitian ini adalah hasil tes kemampuan berpikir kritis matematis, angket kemampuan disposisi, dan wawancara. Subjek penelitian ini yaitu mahasiswa dengan kemampuan disposisi matematis tinggi, sedang, rendah yang selanjutnya diberikan tes kemampuan berpikir kritis matematis. Peneliti melakukan wawancara terkait hasil tes dan melakukan triangulasi waktu untuk melihat kekonsistenan jawaban dari subyek penelitian. Hasil penelitian ini menggambarkan kemampuan berpikir kritis mahasiswa dengan disposisi berkriteria tinggi sudah baik dengan menguasai indikator kemampuan berpikir kritis yaitu memberikan penjelasan sederhana, membangun keterampilan dasar, membuat kesimpulan, memberikan penjelasan lebih lanjut, dan sebagian dari indikator mengatur strategi dan taktik. Sedangkan untuk mahasiswa dengan disposisi berkriteria sedang dan rendah hanya menguasai sebagian indikator yang kelima yaitu indikator mengatur strategi dan taktik. Sehingga kesimpulan dari penelitian ini adalah masih rendahnya kemampuan berpikir kritis matematis mahasiswa.
\end{abstract}

Kata kunci: Disposisi matematis; kemampuan berpikir kritis matematis.

\begin{abstract}
This study aims to examine and analyze mathematical critical thinking ability based on the mathematical disposition abilities of preservice teacher education, especially in geometry courses. This research is considered important because of the demands of $21^{\text {st }}$-century mathematical skills, namely, creativity, critical thinking, communication, and collaboration. This research is a qualitative descriptive study in which the main data in this study are tests of mathematical critical thinking skills, disposition ability questionnaires, and interviews. The subjects of this research are students with high, medium, and low mathematical disposition abilities which are then given a mathematical critical thinking ability test. Researchers conducted interviews related to test results and triangulated time to see the consistency of answers from research subjects. The results of this study illustrate the ability to think critically students with high criteria disposition are already good by mastering critical thinking ability indicators that provide simple explanations, build basic skills, make conclusions, provide further explanation, and some of the indicators set strategy and tactics. Whereas students with moderate and low disposition criteria only mastered some of the fifth indicators namely indicators governing strategy and tactics. So the conclusion of this study is the low mathematical critical thinking ability of students.
\end{abstract}

Keywords: Disposition mathematic; mathematical critical thinking ability.

\section{PENDAHULUAN}

Pembelajaran matematika abad 21 menuntut peserta didik, calon guru, guru, dan dosen untuk mengusai keterampilan 4C yaitu critical thinking (berpikir kritis), creativity (kreativitas), communication (komunikasi), dan collaboration (kerjasama). (Murtiyasa, 
2016) menyebutkan bahwa 4C ini merupakan salah satu strategi untuk menyiapkan para mahasiswa untuk ikut berkompetisi pada masyarakat global. Aspek berpikir kritis membantu mahasiswa untuk berpikir sistemik, dan dapat bernalar secara efektif. Hal ini sejalan dengan hasil penelitian yang dilakukan oleh lebih dari 250 peneliti dari 60 institusi dunia yang tergabung dalam ATC21S (Assessment \& Teaching of 21st Century Skills) yang mengelompokkan keterampilan abad 21 dalam 4 kategori, salah satunya adalah cara berpikir (ATC21S, 2010).

Kemampuan berpikir kritis sangat penting dimiliki oleh calon guru matematika karena tuntutan pembelajaran abad 21 yang mengharuskan mahasiswa memiliki keterampilan 4C. Hal ini dikuatkan dengan rekomendasi dari Committee on the Undergroude Program in Mathematics (Zetriuslita et al., 2016) bahwa setiap mata kuliah dalam matematika hendaknya merupakan aktivitas yang akan membantu mahasiswa dalam pengembangan analitis, penalaran kritis, pemecahan masalah, dan keterampilan komunikasi. Chikiwa \& Schäfer (2018) menyebutkan bahwa berpikir kritis adalah cara seseorang untuk membuat keputusan atau penilaian yang beralasan tentang sesuatu hal. Mahasiswa yang memiliki kemampuan berpikir kritis akan selalu memonitor pemikirannya, memastikan bahwa ia tidak membuat jawaban ataupun kesimpulan yang salah. Selain itu, beberapa ahli Dwyer, Hugan, Stewart menyebutkan bahwa berpikir kritis adalah bagaimana cara seseorang mengambil keputusan pada masalah kompleks yang sedang dihadapinya. Sedangkan Chukwuyenum, (2013) menyebutkan bahwa "Critical Thinking Skills was an effective means of enhancing students' understanding of Mathematics concepts because the skills has helped in interpreting, analysing, evaluating, and presenting date in a logical and sequence manner". Memberikan penjelasan bahwa kemampuan berpikir kritis matematis membuat siswa lebih memahami konsep matematika karena kemampuan tersebut membantu siswa dalam menganalisis serta mengevaluasi.

Selain kemampuan kognitif, mahasiswa calon guru juga harus mempunyai kemampuan afektif yang baik. Ranah afektif pada pembelajaran matematika yang perlu dimiliki salah satunya adalah disposisi matematis. Widyasari, Dahlan, \& Dewanto (2016) menyebutkan bahwa disposisi matematis adalah pengembangan minat dan ketertarikan terhadap matematika. Kusmaryono, Suyitno, Dwijanto, \& Dwidayati (2019) menyebutkan bahwa siswa dituntut untuk dapat menggunakan kemampuan komunikasi, penalaran, menghubungkan ide-ide matematika untuk menyelesaikan masalah, dan mengubah sikap positif terhadap matematika (disposisi matematika positif). Hasil penelitiannya menyebutkan bahwa disposisi matematis sangat penting untuk dikembangkan dalam rangka meningkatkan kemampuan afektif, kognitif dan psikomotorik.

Menurut Sumarmo seseorang yang memiliki disposisi matematis yang tinggi akan membentuk individu yang tangguh, ulet, bertanggung jawab, memiliki motif berprestasi yang tinggi, serta membantu individu mencapai hasil terbaiknya (Widyasari et al., 2016). Sehingga kemampuan dan keterampilan matematis yang kurang dapat mengakibatkan disposisi siswa terhadap matematika juga akan menurun (Kusmaryono \& Dwijanto, 2016). 
Selain itu menurut Katz dalam (Trisnowali, 2015) disposisi matematis berkaitan dengan bagaimana seseorang menyelesaikan masalah matematis; apakah percaya diri, tekun, berminat, dan berpikir fleksibel untuk mengeksplorasi berbagai alternatif penyelesaian masalah. Dari hal yang telah disebutkan di atas maka dapat dikatakan bahwa disposisi matematis merupakan sikap seseorang dalam memandang matematika atau pun kecenderungan seseorang dalam menyelesaikan matematika baik sikap positif maupun sikap negatif.

Penelitian terkait kemampuan berpikir kritis dan disposisi matematis telah dilakukan oleh beberapa peneliti, diantaranya yaitu Kusaeri dan Aditomo tahun 2019. Hasil penelitian Kusaeri dan Aditomo (2019) menyebutkan bahwa calon guru matematika agar memperhatikan dan memberikan lebih banyak penekanan pada pentingnya critical thinking, disposisi matematis, dan peran pembelajaran konstruktivisme dalam mengembangkan kemampuan berpikir kritis (Kusaeri \& Aditomo, 2019). Sedangkan Zetriuslita, Ariawan, \& Nufus (2016) melaporkan dalam penelitiannya terkait kemampuan berpikir kritis mahasiswa berdasarkan level kemampuan mahasiswa yang memberikan hasil bagaimana mahasiswa pada setiap level kemampuan tinggi, sedang dan rendah mampu menjawab soal yang diberikan dan berapa indikator yang mampu dijawab dengan benar. Kemudian penelitian lain yang dilakukan oleh Agoestanto, Sukestiyarno, dan Rochmad (Agoestanto et al., 2019) tentang kemampuan berpikir kritis ditinjau dari gaya kognitif sedangkan pada penelitian ini melihat kemampuan berpikir kritis matematis mahasiswa calon guru berdasarkan kemampuan disposisinya. Hasil penelitian dari Agoestanto dkk menunjukkan bahwa siswa dengan gaya kognitif Field independent memiliki kemampuan berpikir kritis matematis lebih baik jika dibandingkan dengan siswa dengan gaya kognitif field dependent. Siswa dengan gaya kognitif field independent menguasai indikator kemampuan berpikir kritis inferensi, deduksi, memberikan asumsi dan interpretasi. Selanjutnya Kadarsono, Suyitno, \& Waluya (2018) melakukan penelitian tentang kemampuan berpikir kritis matematis pada siswa yang menggunakan pembelajaran CTL ditinjau dari gaya kognitif. Penelitian ini adalah penelitian campuran kuantitatif dan kualitatif. Penelitian memberikan hasil bahwa pembelajaran CTL efektif digunakan untuk meningkatkan kemampuan berpikir kritis matematis dan gaya kognitif memberikan pengaruh terhadap kemampuan berpikir kritis matematis. Selain itu penelitian ini juga memberikan hasil bahwa siswa dengan gaya kognitif field independent mampu menguasai indikator kemampuan berpikir kritis yaitu membuat kesimpulan,deduksi, interpretasi dan mengevaluasi argumen. Penelitian lainnya dilakukan oleh Fitrianna, Dinia, Mayasari, \& Nurhafifah (2018) terkait kemampuan representasi matematis yang ditinjau dari kemampuan disposisi matematis.penelitian ini memberikan hasil bahwa sebagian besar siswa dengan kategori kemampuan disposisi mateamatis sudah mampu menggunakan representasi visualnya dalam menyelesaikan masalah, membuat model matematika, dan menyelesaikan masalah menggunakan ekspresi matematika. Sebaliknya, sebagian besar siswa tidak dapat memenuhi dua indikator kemampuan representasi matematis, yaitu membuat 
sketsa pola geometris dan membuat model matematika berdasarkan situasi dan data yang diberikan. Berikutnya adalah penelitian yang dilakukan oleh (Almerino, Jr. et al., 2019). Penelitian tersebut meneliti tentang affective beliefs sebagai salah satu komponen pada disposisi matematika. Penelitian ini memberikan hasil bahwa affective beliefs memberikan pengaruh terhadap kemampuan disposisi matematis. Kajian teori sebelumnya menyebutkan bahwa disposisi merupakan salah satu bagian dari kemampuan afektif. Hal ini menjadi salah satu alasan mengapa kemampuan disposisi dijadikan tinjauan untuk melihat kemampuan berpikir kritis mahasiswa calon guru.

Pemaparan beberapa penelitian di atas diperoleh bahwa penelitian terkait kemampuan berpikir kritis telah dilakukan dengan mengaitkan sisi afektif siswa maupun mahasiswa yaitu dengan mengaitkan gaya kognitif dan affective belief. Selain itu penelitian tentang disposisi matematis pun telah dilakukan dengan mengaitkan kemampuan matematis yaitu kemampuan representasi. Berdasarkan hal tersebut maka penelitian ini mengarah pada kebaruan dan orisinalitas berkaitan dengan kemampuan berpikir kritis matematis ditinjau dari kemampuan disposisi matematis.

Kemampuan berpikir kritis yang merupakan bagian dari keterampilan 4C menjadi penting untuk diteliti sebagai pemetaan kemampuan calon guru matematika. Kemampuan berpikir kritis sangat penting dimiliki oleh calon guru matematika karena tuntutan pembelajaran abad 21 yang mengharuskan siswa memiliki ketrampilan 4C sehingga sebagai calon guru pun harus memiliki kemampuan ini. Penelitian tentang tingkat pengetahuan guru dalam keterampilan 4C yang dilakukan oleh Elva Susanti dan Anggia Arista (Susanti \& Arista, 2019) menyatakan bahwa $19 \%$ memiliki kemampuan tinggi, 51\% kemampuan sedang, dan 30\% kemampuan rendah. Sedangkan untuk masing-masing kompetensi, kompetensi komunikasi lah paling tinggi yaitu sebesar 51.85\%. Oleh sebab itu, perlu dilakukan pemetaan pada calon guru matematika untuk mengetahui kesiapan calon guru dalam menghadapi tantangan pendidikan di abad 21.

Berdasarkan uraian latar belakang tersebut, maka penelitian ini bertujuan menganalisis secara mendalam tentang kemampuan berpikir kitis matematis mahasiswa calon guru matematika ditinjau dari kemampuan disposisi matematis siswa.

\section{METODE PENELITIAN}

Jenis penelitian yang dilakukan pada penelitian ini adalah penelitian deskriptif kualitatif. Penelitian ini dilakukan di Universitas Muhammadiyah Prof. Dr. HAMKA (UHAMKA) yang dilaksanakan pada semester ganjil tahun pelajaran 2019/2020.

Subjek pada penelitian ini adalah mahasiswa program studi pendidikan matematika yang berjumlah 3 orang. Pemilihan subjek berdasarkan kategori disposisi matematis tinggi, sedang, rendah. Selain itu pemilihan subjek juga didasarkan pada nilai awal calon subjek penelitian. Subjek penelitian yang dipilih harus memiliki nilai awal yang sama baik untuk kategori disposisi matematis tinggi, sedang, ataupun rendah. Setelah dilakukan pengukuran disposisi matematis didapatkan rangkuman hasil pengukuran.

Instrumen pengumpulan data penelitian yang digunakan adalah tes 
kemampuan berpikir kritis matematis, angket diposisi matematis dan wawancara yang dilakukan antara peneliti dan subjek penelitian. Penelitian ini menggunakan triangulasi waktu untuk menguji keabsahan data penelitian. Langkah pengumpulan data dalam penelitian ini, yaitu mengelompokkan subjek penelitian berdasarkan disposisi matematis tinggi, sedang, dan rendah serta berdasarkan kriteria yang telah ditentukan. Kemudian melaksanakan pengambilan data kemampuan berpikir kritis matematis mahasiswa dengan cara sebagai berikut: (1) meminta mahasiswa mengerjakan soal yang sudah disusun sehingga memenuhi indikator kemampuan berpikir kritis matematis; (2) memberikan pertanyaan kepada mahasiswa terkait dengan hasil pengerjaan soalnya, (3) menganalisis data mahasiswa, (4) melaksanakan pengambilan data kedua. Hal ini dilakukan untuk membandingkan data pada pengambilan data pertama. (5) membandingkan hasil pengambilan data pertama dan pengambilan data kedua. (6) menyimpulkan hasil analisis kemampuan berpikir kritis matematis mahasiswa berdasarkan disposisi, tinggi, sedang, dan rendah.

Indikator kemampuan berpikir kritis yang digunakan dalam penelitian ini adalah (1) memberikan penjelasan sederhana: bertanya atau menjawab pertanyaan dengan memberikan penejelasan sederhana; (2) membangun keterampilan dasar: menggunakan prosedur yang tepat dan memberikan alasan dari penyelesaian yang diberikan; (3) membuat kesimpulan: menginduksi dan menarik kesimpulan sesuai fakta hasil penyelidikan; (4) memberikan penjelasan lebih lanjut: mendefinisikan istilah dan menggunakan definisi untuk memberikan penejelasan lebih lanjut;
(5) mengatur strategi dan taktik: menentukan suatu tindakan dalam menyelesaikan masalah dan merumuskan solusi alternatif dalam menyelesaikan masalah.

Indikator disposisi matematis yang digunakan dalam penelitian ini disajikan pada Tabel 1.

Tabel 1. Indikator disposisi matematis.

\begin{tabular}{|c|c|}
\hline Aspek & Indikator \\
\hline $\begin{array}{l}\text { Kepercayaan } \\
\text { diri }\end{array}$ & $\begin{array}{l}\text { Percaya diri terhadap } \\
\text { kemajuan atau keyakinannya }\end{array}$ \\
\hline $\begin{array}{l}\text { Keingin- } \\
\text { tahuan }\end{array}$ & $\begin{array}{lr}\text { Sering } & \text { mengajukan } \\
\text { pertanyaan, } & \text { melakukan } \\
\text { penyelidikan, } & \\
\text { antusias/semangat } & \text { dalam } \\
\text { belajar, dan } & \text { banyak } \\
\text { membaca/mencari sumber lain }\end{array}$ \\
\hline Ketekunan & $\begin{array}{l}\text { Gigih/tekun/perhatian/kesungg } \\
\text { uhan }\end{array}$ \\
\hline Fleksibilitas & $\begin{array}{l}\text { Kerjasama/berbagi } \\
\text { pengetahuan, menghargai } \\
\text { pendapat yang berbeda, } \\
\text { berusaha } \\
\text { solusi/strategi lain, }\end{array}$ \\
\hline Reflektif & $\begin{array}{l}\text { Bertindak dan berhubunngan } \\
\text { dengan matematika, } \\
\text { menyukai/rasa senang terhadap } \\
\text { matematika }\end{array}$ \\
\hline
\end{tabular}

Tabel 2. Rangkuman hasil pengukuran disposisi matematis.

\begin{tabular}{|c|c|c|}
\hline \multicolumn{3}{|c|}{$\begin{array}{l}\text { Jumlah Mahasiswa Kategori Disposisi } \\
\text { Matematis }\end{array}$} \\
\hline Tinggi & Sedang & Rendah \\
\hline 10 orang & 7 orang & 12 orang \\
\hline $34,48 \%$ & $24,13 \%$ & $41,37 \%$ \\
\hline $\begin{array}{l}\text { Keterangan: } \\
\text { Max = data } \\
\text { Min = data } n\end{array}$ & $\mathrm{um}_{\mathrm{n}}$ & \\
\hline
\end{tabular}

Berdasarkan hasil pengelompokan pada Tabel 2 selanjutnya dipilih 1 subjek untuk masing-masing disposisi matematis tinggi, sedang, dan rendah. Pemilihan subyek selain berdasarkan kriteria disposisi matematis tinggi, sedang, dan rendah, subyek yang akan 
diteliti juga dipilih berdasarkan jenis kelamin dan kemampuan awal yaitu mahasiswa yang berjenis kelamin sama dan memiliki kemampuan awal yang sama (Tabel 3).

Tabel 3. Subyek penelitian terpilih.

\begin{tabular}{ccccc}
\hline $\begin{array}{c}\text { Disposisi } \\
\text { Matematis }\end{array}$ & Subyek & $\begin{array}{c}\text { Jenis } \\
\text { Kelamin } \\
(\mathbf{P} / \mathbf{L})\end{array}$ & $\begin{array}{c}\text { Skor } \\
\text { Angket }\end{array}$ & $\begin{array}{c}\text { Nilai } \\
\text { Awal }\end{array}$ \\
\hline Tinggi & RAT (S1) & P & 106 & 73 \\
\hline Sedang & LK (S2) & P & 102 & 73 \\
\hline Rendah & DP (S3) & P & 96 & 73 \\
\hline
\end{tabular}

Tahap analisis data pada penelitian ini yaitu mengumpulkan data melalui hasil pengerjaan soal kemampuan berpikir kritis dan wawancara yang mendalam terhadap jawaban mahasiswa yang kemudian ditranskripkan secara lengkap dan menggolongkan data menjadi tiga bagian yaitu mahasiswa yang berdasarkan disposisi tinggi, sedang, dan rendah. Kemudian data disajikan dalam bentuk teks naratif tentang bagaimana penggunaan kemampuan berpikir kritis matematisnya. Setelah itu dilakukan penarikan kesimpulan dan verifikasi yang akan menjadi temuan baru berupa kemampuan berpikir kritis matematis dari masing-masing subjek penelitian.

\section{HASIL DAN PEMBAHASAN}

Data penelitian ini berupa data hasil tes kemampuan berpikir kritis matematis dan wawancara. Data hasil wawancara oleh setiap subjek pada masing-masing kategori disposisi matematis ditranskripkan dan dipaparkan untuk mengetahui kemampuan berpikir kritis matematis subjek.

Hasil tes kemampuan berpikir kritis pada kategori disposisi matematis tinggi, sedang, rendah disajikan pada gambar Gambar 1-6.

\section{Subjek dengan Disposisi Matematis Tinggi (S1)}

Gambar 1 dan 2 adalah hasil tes kemampuan berpikir kritis subjek $\mathrm{S} 1$ pada tes kemampuan berpikir kritis 1 dan 2 .

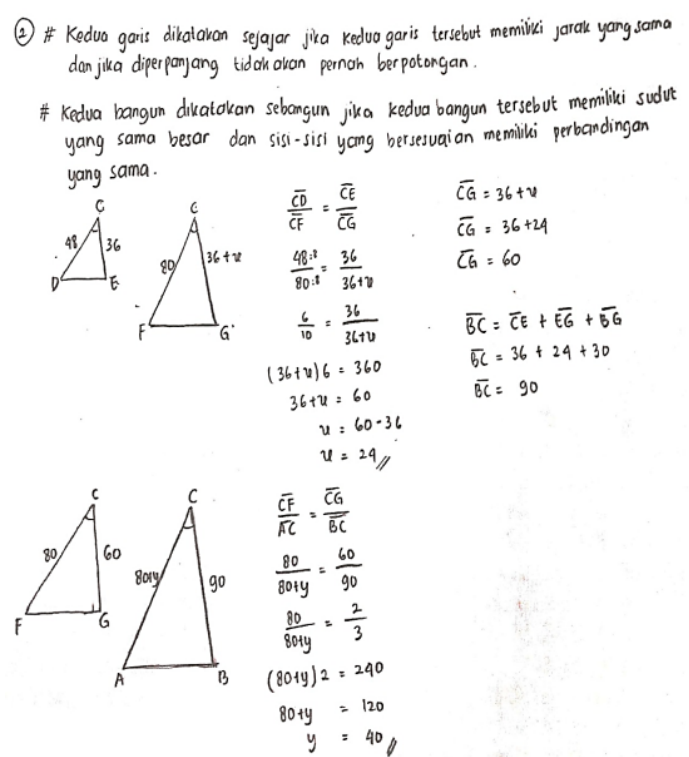

Gambar 1. Jawaban S1 pada Tes Kemampuan Berpikir Kritis 1

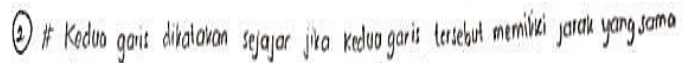

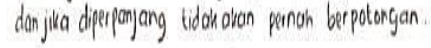

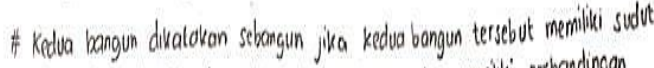

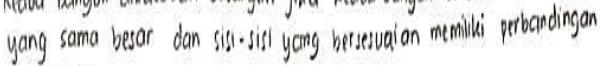

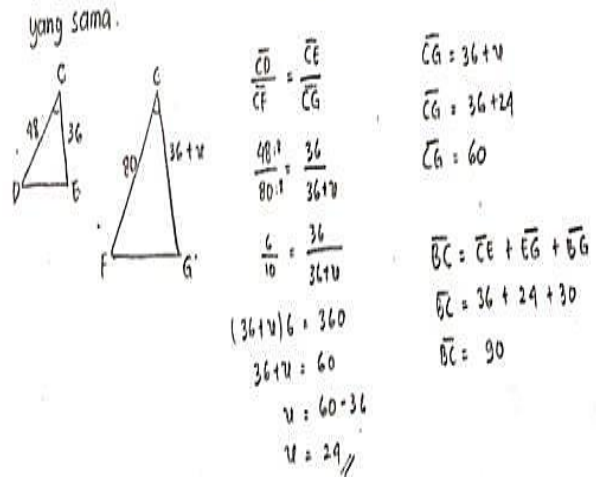

Gambar 2. Jawaban S1 pada tes kemampuan berpikir kritis 2 . 
DOI: https://doi.org/10.24127/ajpm.v9i2.2703

Berdasarkan hasil tes dan wawancara yang telah dilakukan terlihat bahwa subjek S1 mampu menyelesaikan permasalahan yang diberikan dengan tepat. Subjek S1 juga mampu mendefinisikan kesejajaran dan kesebangunan dengan tepat selain itu subjek S1 juga menggunakan definisi tersebut untuk menyelesaikan soal tersebut. Subjek S1 menggunakan konsep kesebangunan untuk mencari nilai $x$ dan $y$ yang menjadi pertanyaan.

\section{Subjek dengan Disposisi Matematis Sedang (S2)}

Gambar 3 adalah hasil tes kemampuan berpikir kritis subjek S2 pada tes kemampuan berpikir kritis 1 dan 2.

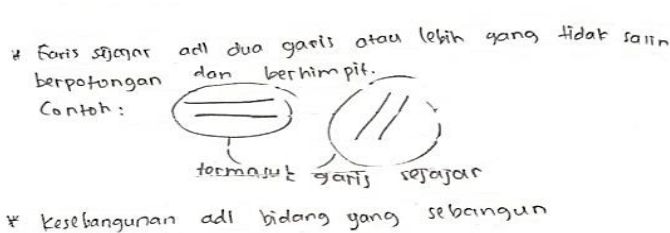

$$
\begin{array}{rlrl}
* E G & =\frac{C E+C B}{2} & A F & =\frac{A D+A C}{2} \\
x & =\frac{36 \mathrm{~cm}}{2}+30 \mathrm{~cm} & y & =\frac{32 \mathrm{~cm}+80 \mathrm{~cm}}{2} \\
& =\frac{66}{2} & y & =\frac{112 \mathrm{~cm}}{2} \\
& =33 \mathrm{~cm} ; & y & =56 \mathrm{~cm}
\end{array}
$$

Gambar 3. Jawaban S2 pada tes kemampuan berpikir kritis 1 .

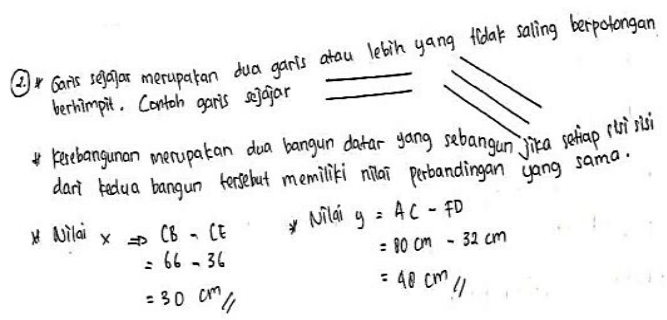

Gambar 4. Jawaban S2 pada tes kemampuan berpikir kritis 2 .

Berdasarkan hasil tes (Gambar 4) dan wawancara yang telah dilakukan terlihat bahwa subjek S2 belum dapat

menyelesaikan permasalahan dengan tepat. Subjek S2 juga belum mendefinikan kesejajaran dan kesebangunan dengan benar. Padahal konsep dari kesebangunan dan kesejajaran itu digunakan untuk menyelesaikan masalah yang diberikan. Subjek S2 memberikan penyelesaian masalah hanya berdasarkan perkiraan bukan berdasarkan konsep yang benar.

\section{Subjek dengan Disposisi Matematis Rendah (S3)}

Gambar 5 dan 6 adalah hasil tes kemampuan berpikir kritis subjek S2 pada tes kemampuan berpikir kritis 1 dan 2.

2

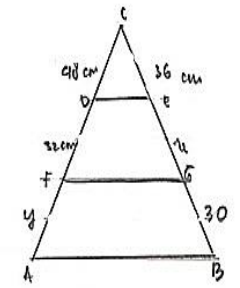

Garis Sejajar $\rightarrow$ Garis yans sejagar iys tidak ber potongan kurcbangunan of ban's yang terbentite kesebangunar.

mempunyai mang hilai yo berbeda.

Gambar 5. Jawaban S3 pada tes kemampuan berpikir kritis 1

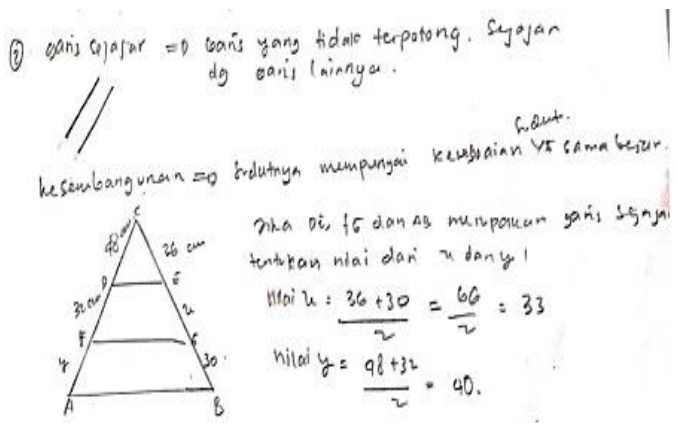

Gambar 6. Jawaban S3 pada tes kemampuan berpikir kritis 2

Berdasarkan hasil tes dan wawancara yang telah dilakukan terlihat bahwa subjek S3 masih belum memberikan definisi yang benar tentang kesejajaran dan kesebangunan. 
Karena pemahaman tentang konsep kesebangunan masih kurang mengakibatkan subjek S3 tidak bisa menyelesaikan pertanyaan nomor 2 dengan benar. Konsep yang digunakan untuk mencari nilai $x$ dan $y$ adalah konsep yang salah dan tidak ada di matematika.

Kemampuan berpikir kritis matematis adalah kemampuan yang penting untuk dimiliki oleh calon guru matematika. Namun ternyata kemampuan berpikir kritis matematis yang dimiliki oleh calon guru matematika masih tergolong rendah. Hal tersebut terlihat dari hasil analisis penelitian ini yang menyimpulkan bahwa calon guru matematika hanya mampu menguasai beberapa indikator kemampuan berpikir kritis matematis. Hasil di atas menjadi catatan bagi peneliti bahwa sebagai calon guru masih terdapat mahasiswa yang memiliki disposisi matematis sedang dan rendah. Rendahnya disposisi matematis sejalan dengan rendahnya kemampuan berpikir kritisnya. Lemahnya konsep matematis mahasiswa menjadi salah satu alasan mengapa kemampuan berpikir kritis mahasiswa calon guru masih rendah. Penelitan (Chukwuyenum, 2013) menyebutkan bahwa pemahaman konsep siswa sangat berpengaruh terhadap kemampuan berpikir kritis matematis. Oleh karena itu direkomendasikan kemampuan berpikir kritis harus dimasukkan dalam kurikulum pendidikan bagi calon guru sehingga sehingga guru dapat memfasilitasi peningkatan kemampuan berpikir kritis siswa di sekolah. Hasil penelitian dari Kusaeri \& Aditomo (2019) menyebutkan bahwa sangat perlu kesadaran guru matematika untuk memberikan lebih banyak penekanan pada pentingnya kemampuan berpikir kritis matematis dan dimensi disposisi matematis.

\section{KESIMPULAN DAN SARAN}

Kesimpulan pada penelitian ini adalah calon guru matematika yang memiliki disposisi matematis tinggi cenderung menguasai kemampuan berpikir kritis matematis, sedangkan calon guru matematika yang memiliki disposisi matematis sedang dan rendah cenderung belum menguasai kemampuan berpikir kritis matematis.

Saran untuk penelitian selanjutnya adalah peneliti dapat meneliti kemampuan berpikir kritis matematis dengan mengaitkan aspek kognitif lainnya. Selain itu dalam melakukan wawancara diharapkan dapat menggali informasi lebih dalam untuk memperkuat hasil penelitian tersebut.

\section{DAFTAR PUSTAKA}

Agoestanto, A., Sukestiyarno, Y. L., \& Permanawati, F. I. (2019). Kemampuan Menganalisis Argumen dalam Berpikir Kritis Ditinjau dari Rasa Ingin Tahu. PRISMA, Prosiding Seminar Nasional Matematika, 2, 337-342. https://journal.unnes.ac.id/sju/inde x.php/prisma/article/download/289 48/12660/

Agoestanto, A., Sukestiyarno, Y. L., \& Rochmad. (2016). Analysis of Mathematics Critical Thinking Students in Junior High School Based on Cognitive Style. Journal of Physics: Conference Series, 755(1).

https://doi.org/10.1088/1742-

6596/755/1/011001

Almerino, Jr., P. M., Etcuban, J. O., De Jose, C. G., \& Almerino, J. G. F. (2019). Students' Affective Belief 
DOI: https://doi.org/10.24127/ajpm.v9i2.2703

as the Component in Mathematical Disposition. International Electronic Journal of Mathematics Education, 14(3), 475-487. https://doi.org/10.29333/iejme/575 0

ATC21S. (2010). Assesment \& Teaching of 21st Century Skills Status Report as of January 2010. ATCs21s, 1-4. https://www.cisco.com/c/dam/en_u s/about/citizenship/socioeconomic/docs/ATC21S_Exec_Su mmary.pdf

Chikiwa, C., \& Schäfer, M. (2018). Promoting critical thinking in multilingual mathematics classes through questioning. Eurasia Journal of Mathematics, Science and Technology Education, 14(8). https://doi.org/10.29333/ejmste/91 832

Chukwuyenum, A. N. (2013). Impact of Critical thinking on Performance in Mathematics among Senior Secondary School Students in Lagos State. IOSR Journal of Research \& Method in Education (IOSRJRME), 3(5), 18-25. https://doi.org/10.9790/73880351825

Fitrianna, A. Y., Dinia, S., Mayasari, M., \& Nurhafifah, A. Y. (2018). Mathematical Representation Ability of Senior High School Students: An Evaluation from Students' Mathematical Disposition. JRAMathEdu (Journal of Research and Advances in Mathematics Education), 3(1), 46. https://doi.org/10.23917/jramathed u.v3i1.5872

Kadarsono, M., Suyitno, H., \& Waluya, B. (2018). Mathematical Critical
Thinking Ability of Students in CTL Learning Based on Cognitive Style. Unnes Journal of Mathematics Education Research, 7(2), 1-7.

Kusaeri, \& Aditomo, A. (2019). Pedagogical beliefs about Critical Thinking among Indonesian mathematics pre-service teachers. International Journal of Instruction, 12(1), 573-590. https://doi.org/10.29333/iji.2019.1 $2137 \mathrm{a}$

Kusmaryono, I., \& Dwijanto, D. (2016). Peranan Representasi Dan Disposisi Matematis Siswa Terhadap Peningkatan Mathematical Power. JIPMat, 1(1), 19-28. https://doi.org/10.26877/jipmat.v1i 1.1089

Kusmaryono, I., Suyitno, H., Dwijanto, D., \& Dwidayati, N. (2019). The effect of mathematical disposition on mathematical power formation: Review of dispositional mental functions. International Journal of Instruction, 12(1), 343-356. https://doi.org/10.29333/iji.2019.1 $2123 \mathrm{a}$

Murtiyasa, B. (2016). Isu-Isu Kunci Dan Tren Penelitian Pendidikan Matematika. Prosiding Konferensi Nasional Penelitian Matematika Dan Pembelajarannya (KNPMP I) Universitas Muhammadiyah Surakarta, 1-10.

Nurfitriyanti, M. (2017). Peningkatan Kemampuan Disposisi Matematika Melalui Pembelajaran Berbasis Aktivitas Siswa. Jurnal Susunan Artikel Pendidikan, 2(1), 84-93. https://doi.org/https://dx.doi.org/10 .30998/sap.v2i1.1726 
DOI: https://doi.org/10.24127/ajpm.v9i2.2703

Susanti, E., \& Arista, A. (2019). Analisa

Tingkat Pengetahuan Guru terhadap Kompetensi 4C.

Prosiding Seminar Nasional Ilmu Sosial Dan Teknologi (SNISTEK), September, 73-78. http://ejournal.upbatam.ac.id/index .php/prosiding/article/view/1509

Trisnowali, A. (2015). Profil Disposisi Matematis Siswa Pemenang Olimpiade Pada Tingkat Provinsi Sulawesi Selatan. Journal of Educational Science and Technology (EST), 1(3), 47-57. https://doi.org/10.26858/est.v1i3.1 826

Widyasari, N., Dahlan, J. A., \& Dewanto, S. (2016). Meningkatkan Kemampuan Disposisi Matematis Siswa SMP Melalui Pendekatan Metaphorical Thinking. FIBONACCI: Jurnal Pendidikan Matematika Dan Matematika, 2(2), 28-39.

https://doi.org/10.24853/fbc.2.2.28 $-39$

Zetriuslita, Z., Ariawan, R., \& Nufus, H. (2016). Analisis Kemampuan Berpikir Kritis Matematis Mahasiswa Dalam Menyelesaikan Soal Uraian Kalkulus Integral Berdasarkan Level Kemampuan Mahasiswa. Infinity Journal, 5(1), 56-65. https://doi.org/10.22460/infinity.v5 i1.193 